tants of the world, and at each successive period between the extinct and still older species, why is not every geological formation charged with such links? Why does not every collection of fossil remains afford plain evidence of the gradation and mutation of the forms of life? We meet with no such evidence, and this is the most obvious and plausible of the many objections which may be urged against my theory." 1

Nothing could have been more useful to the opposition than this characteristically candid avowal, twisted as it immediately was into an admission that the writer's views were contradicted by the facts of palæontology. But, in fact, Mr: Darwin made no such admission. What he says in effect is, not that palæontological evidence is against him, but that it is not distinctly in his favour; and without attempting to attenuate the fact, he accounts for it by the scantiness and the imperfection ;of that evidence.

What is the state of the case now, when, as we have seen, the amount of our knowledge respecting the mammalia of the Tertiary epoch is increased fifty-fold, and in some directions even approaches completeness?

Simply this, that if the doctrine of Evolution had not existed palæontologists must have invented it, so irresistibly is it forced upon the mind by the study of the remains of the Tertiary mammalia which have been brought to light since 1859 .

Among the fossils of Pikermi, Gaudry found the successive stages by which the ancient civets passed into the more modern hyænas; through the Tertiary deposits of Western America, Marsh tracked the successive forms by which the ancient stock of the horse has passed into its present form ; and innumerable less complete indications of the mode of evolution of other groups of the higher mammalia have been obtained.

In the remarkable memoir on the Phosphorites of Quercy, to which I have referred, M. Filhol describes no fewer than seventeen varieties of the genus Cynodictis, which fill up all the interval between the viverine animals and the bear-like $\operatorname{dog}$ Amphicyon; nor do I know any solid ground of objection to the supposition that in this Cynodictis-Amphicyon group we have the stock whence all the Viveridæ, Felidæ, Hyænidæ, Canidæ, and perhaps the Procyonidæ and Ursidæ, of the present fauna have been evolved. On the contrary, there is a great deal to be said in its favour.

In the course of summing up his results, M. Filhol observes $^{2}$ :-

"During the epoch of the phosphorites, great changes took place in animal forms, and almost the same types as those which now exist became defined from one another.

"Under the influence of natural conditions of which we have no exact knowledge, though traces of them are discoverable, species have been modified in a thousand ways: races have arisen which, becoming fixed, have thus produced a corresponding number of secondary species."

In 1859, language of which this is an unintentional paraphrase, occurring in the "Origin of Species," was scouted as wild speculation ; at present, it is a sober statement of the conclusions to which an acute and criticallyminded investigator is led by large and patient study of the facts of palæontology. I venture to repeat what I have said before, that, so far as the animal world is conI "Origin of Species, ed. x. p. 463 . 2 This passage was omitted in the delivery of the lecture. cerned, Evolution is no longer a speculation, but a state. ment of historical fact. It takes its place alongside of those accepted truths which must be taken into account by philosophers of all schools.

Thus when, on the first day of October next, the "Origin of Species" comes of age, the promise of its youth will be amply fiulfilled; and we shall be prepared to congratulate the venerated author of the book, not only that the greatness of his achievement and its enduring influence upon the progress of knowledge have won him a place beside our Harvey; but, still more, that, like Harvey, he has lived long enough to outlast detraction and opposition, and to see the stone that the builders rejected become the head-stone of the corner.

T. H. HuXLEY

\section{ON MULTIPLE SPECTRA}

" Nunc age, quo motu genitalia materiai Corpora res varias gignant, genitasque resolvant Et qua vi facere id cogantur."

$$
\text { Lucretius, ii., 6I-2. }
$$

“ Prima moventur enim per se primordia rerum : Inde ea, quæ parvo sunt corpora conciliatu, Et quasi proxima sunt ad vireis principiorum, Ictibus illorum cæcis impulsa cientur

Ipsaque, quæ porro paulo maiora, lacessunt." Lacretius, ii. I32-6.

"It is conceivable that the various kinds of matters, now recognised in different elementary substances, may possess one and the same ultimate or atomic molecule existing in different conditions of movement.

"The essential unity of matter is an hypothesis in harmony with the equal action of gravity upon all bodies."-Grahan's Researches, p. 299.

$\mathrm{T}$ a recent paper ${ }^{1} \mathrm{I}$ showed that a study of the minute 1 anatomy of spectra, both terrestrial and celestial, forces upon us the conclusion that both in the eleciric arc and in the hottest region of the sun the so-called chemical elements behave after the manner of compound bodies.

I then dealt more especially with the question of the basic lines in the various spectra, and it is clear that if, at any one temperature, there be some lines only truly basic in the spectrum of any element, we at once divide the lines visible at that temperature into two groups, those which are basic and those which are not. This would give a compound origin to the lines, and this is the rea! point.

It is now years ago since the view was first held that the elementary bodies had double spectra, that is, that each, or at all events several, under changed conditions of temperature or electric tension, gave us now a fluted spectrum and now one composed of lines.

I glimpsed the idea some time afterwards that the line spectrum was in its turn in all probability a complex: whole, in other words that it was the stimmation of the spectra of various molecular groupings.

Recent work has to my mind not only shown that this is true, but that in the case of many bodies the complexity, and therefore the number, of the molecular groupings which give rise to that compound whole called a line spectrum, is considerable.

It is therefore important from my point of view to reconsider the evidence on which the assertion that the

I "On the Necessity for a N New Departure in Spectrum Analysis" (NATURe, vol. xxi. p. 8). 
fluted bands and the line spectrum (taken as a whole) of a substance really belong to that substance, because if we find that this must be accepted and that it can easily be explained on the view that the two kinds of spectra are produced by different molecular groupings, the fact of other molecular groupings giving rise to a complex line spectrum can be more readily accepted, contrary though it be to modern "chemical philosophy," as taught at all events in the text-books.

Plucker and Hittorf were, I believe, the first to point out that the same chemical substance, when in a state of gas or vapour, gave out different spectra under different conditions. On this point they wrote fifteen years ago:-

"The first fact which we discovered in operating with our tubes ... . was the following one :-

"There is a certain number of elementary substances which, when differently heated, furnish two kinds of spectra of quite a different character, not having any line or any band in common.

"The fact is important, as well with regard to theoretical conceptions as to practical applications-the more so as the passage from one kind of spectrum to the other is by no means a continuous one, but takes place abruptly. By regulating the temperature you may repeat the two spectra in any succession ad libitum." (Plucker and Hittorf on the Spectra of Ignited Gases and Vapours: Phil. Trans. Royal Society, I865, part i. p. 6.)

Ångström, whose name must ever be mentioned with the highest respect by any worker in spectrum analysis, was distinctly opposed to this view, and in the text which accompanies his Spectre Normal we find the following statement-

"Dans un Mémoire sur les spectres 'doubles' des corps élémentaires que nous publierons prochaînement, M. Thalén et moi, dans les Actes de la Société des Sciences d'Upsal, nous traiterons d'une manière suffisamment complete les questions importantes qu'on peut se proposer sur cet intéressant sujet. Pour le présent, je me borne à dire que les résultats auxquels nous sommes arrivés, ne confirment aucunement l'opinion émise par Pliicker, qu'un corps élémentaire pourrait donner, suivant sa température plus ou moins élevée, des spectres tout-àfait différents. C'est le contraire qui est exact. En effet en augmentant successivement la température, on trouve que les raies varient en intensité d'une manière trèscompliquée, et que, par suite, de nouvelles raies peuvent même se présenter, si la température s'élève suffisamment. Mais, independamment de toutes ces mutations, le spectre d'un certain corps conservera toujours son caractère individuel." ${ }^{\mathrm{x}}$

Ångström did not object merely on theoretical grounds. He saw, or thought he saw, room to ascribe all these fluted spectra to impurities.

He was strengthened in this view by observing how, in the case of the spectra of known compounds, there were always flutings in one part of the spectrum or another; a rapid induction naturally, therefore, ascribed all flutings to compounds. The continuity of the gaseous and liquid states of matter, let alone the continuity of Nature's processes generally, never entered into the question. For Ångström, as for the modern chemist, there was no such thing as evolution, no possibility of a close physical relationship between elements, so called, driven to incandescence from the solid state, and binary compounds of those elements.

1.Angström sur "Le Spectre normal du Soleil," page 39.
In a memoir, however, which appeared after Ângström's death, and which, though under a different title, was in all probability the one referred to, this opinion was to a large extent recalled, and in favour of Plucker's view, in the following words:-

"... Nous ne nions certainement pas qu'un corps simple ne puisse dans certains cas donner differents spectres. Citons, par exemple, le spectre d'absorption d'iode que ne ressemble en aucune façon au système des raies brillantes du même corps, obtenues au moyen de l'électricité ; et remarquons de plus qu'en général tout corps simple, presentant la propriété d'allotropie, doit donner à l'état d'incandescence des spectres différents, pourvu que la dite propriété de la substance subsiste non seulement à l'état gazeux du corps, mais encore à la température même de l'incandescence. . . .

"Le soufre solid possède, somme on sait, plusieurs états allotropiques, et, d'après certaines observations, ce corps, même à son état gazeux, prendrait des formes différentes. Par conséquent, en supposant que cela soit vrai, le soufre gazeux doit donner plusieurs spectres d'absorptio, tandis que la possibilité d'un seul on de plusieurs spectres brillants dépendra de la circonstance suivante, savoir si les états allotropiques plus complexes de cette substance supporteront la température de l'incandescence, avant de se décomposer.

"Il est bien évident que les cas dont nous venons de parler, ne forment pas une exception à la loi générale énoncée ci-dessus, savoir que chaque corps simple ne peut donner qu'un seul spectre. En effet, si l'on suppose que l'état allotropique est dû à la constitution moléculaire du corps, soit que les molécules se combinent les unes avec les autres, soit qu'elles s'arrangent entre elles d'une certaine manière, cet état allotropique possèdera au point de vue spectroscopique, toutes les propriétés significatives d'un corps composé, et par conséquent il doit être décomposé de la même façon que celui-ci par les effets de la décharge disruptive de l'électricité."1

I say that in this paper Angström recalled his own in favour of Plucker's view, because (as it has been remarked by Dr. Schuster ${ }^{2}$ ) the word "element" is used in a special sense-because in reality allotropic states are classed as compounds, that particular allotropic state which is to be regarded as truly elemental not being stated, nor any reason given why one should be thus singled out.

In the letter to which I have just referred Dr. Schuster gives an instance in which in order to show that elementary bodies did not really possess two spectra, a double spectrum was assigned to an acknowledged compound; the fluted spectra of hydrogen and carbon which differ from each other as widely as fluted spectra can, being both ascribed to acetylene.

Salet in his admirable work on the Spectra of the Metalloids, ${ }^{3}$ was driven to the conclusion that many of these bodies must be held to possess two spectra. His conclusions are thus expressed:-

"Nous avons comparé le spectre d'absorption du brome et de l'iode à leur spectre électrique, et cette comparaison nous semble mettre hors de doute la possibilité des spectres doubles. ... .

"Nous avons obtenu, par voie électrique, un spectre primaire de l'iode correspondant à son spectre d'absorption. Le soufre, le sélénium et le tellure nous ont offert des spectres de combustion très-analogues aux spectres primaire obtenus par voie électrique, mais différant essentiellement des spectres des lignes. . . .

\footnotetext{
s Angström and Thalén's "Recherches sur les Spectres des Métalloides," p. 5 .
${ }_{3}$ Ann. de Chimie et de Physique, 1873 , vol. xxviii. p. x.
} 
"Nous avons produit le spectre primaire de l'azote avec différents corps qui n'ont absolument de commun que l'azote; nous pensons donc avoir démontré qu'il appartient bien réellement à ce métallö̈de." (Annales de Chemie et de Physique, 4 série, tome xxviii. pp. 70, 71).

In 1868 Wullner ${ }^{1}$ gave his attention to this subject, and strongly supported Plucker's view of the existence of double spectra, indicating at the same time that the difference of temperature must be regarded as the sole cause of the phenomenon, adding, however, "a decomposition with further elements is not to be thought of." In the case of hydrogen he showed that the banded spectrum ascribed to acetylene really depended upon a change in the emissive power brought about by an alteration of temperature. Touching oxygen, he showed that three distinct spectra may be obtained, while in nitrogen two are observed.

I may say that in my early laboratory experiments I was at first led to think that, in the case of metallic vapours, Ångström's first expressed opinion was correct, and I said so. But after more experience and knowledge had been acquired, I was compelled by the stern logic of facts to abandon it, and I showed, first, that more "orders" of spectra-to use Plucker's term-were necessary, and then that the line spectrum itself was in all probability compound ; that is, that it was in some cases built up by the vibration of dissimilar molecules, some of which might even give us a fluted spectrum, if we could study them alone.

Although, however, in the views I have expressed on former occasions I have had the advantage of the support of the opinion of Plucker and Angstrom, and later of Dr. Schuster, ${ }^{2}$ not to mention others, I am aware that though there is a general consensus among spectroscopic workers that double spectra cannot be ascribed to impurities, it is not absolute.

I propose therefore in this place to refer to a special case in which this question has been recently brought prominently forward.

I have already stated that Angström, who was the first to map the line-spectrum of carbon, ascribed the flutings ordinarily seen in the carbon compounds to acetylene.

Now Attfield, in 1862 , as a result of a most carefully conducted and admirably-planned set of experiments, came to the conclusion that the flutings were really due to carbon: in short, that carbon, like hydrogen, iodine, sulphur, nitrogen, and other bodies, had a fluted spectrum as well as one consisting wholly of lines.

The work of Attfield will be gathered from the following extract from his paper (Phil. Trans., vol. clii. part r, p. 221 et seq.) :-

"On recently reading Swan's paper by the light that

IPhil. Mag., sec. 4, vol. xxxvii. p. 405.

2 Dr. Schuster's recently published investigations are as follows:-

Mr. Lockyer's investigations have shown that most bodies give us a continuous spectrum, as a gas, before they condense, and many at a con siderable temperature above the boiling point. Mr. Lockyer has rightly drazen the conclusion from these facts, that the atomic aggregation of the molecules is the cause of the different orders of spectra.

That the discontinuous spectra of different orders (line and band spectra) are due to different molecular combination, I consider to be pretty well established, and analogy has led me (and Mr. Lockyer befcre me) to expla the continuous spectra by the same cause; for the change of the continuous spectrum to the line or band spectrum to the line or band-spectrum takes place in exactly the same way as strong gide, yet some diong (Dr. A. Schuster on the Spectra of Metalloids, Phil. Trans. Royal Society, 1879. Part i page 3 and 89 , ncte)
Professors Bunsen and Kirchhoff have thrown on the subject, I came to the conclusion that these bands must be due to incandescent carbon vapour; that, if so, they must be absent from flames in which carbon is absent, and present in flames in which carbon is present; that they must be observable equally in the flames of the oxide, sulphide, and nitride as in that of the hydride of carbon ; and, finally, that they must be present whether the incandescence be produced by the chemical force, as in burning jets of the gases in the open air, or by the electric force, as when hermetically-sealed tubes of the gases are exposed to the discharge of a powerful inductioncoil. . . .

"To establish the absolute identity of the hydro- and nitro-carbon spectra, excluding of course the lines due to nitrogen, they were simultaneously brought into the field of the spectroscope: one occupying the upper, and the other the lower half of the field.

" This was readily effected after fixing the small prism, usually supplied with spectroscopes, over half of the narrow slit at the further end of the object-tube of the instrument. The light from the oxyhydrocarbon flame was now directed up the axis of the tube by reflection from the little prism, while that from the oxynitrocarbon flame passed directly through the uncovered half of the slit. A glance through the eye-tube was sufficient to show that the characteristic lines of the hydrocarbon spectrum were perfectly continued in the nitrocarbon spectrum. A similar arrangement of apparatus, in which the hydrocarbon light was replaced by that of pure nitrogen, showed that the remaining lines of the nitrocarbon spectrum were identical with those of the nitrogen spectrum. In this last experiment the source of the pure nitrogen light was the electric discharge through the rarefied gas.

"The above experiment certainly seemed to go far towards proving the spectrum in question to be that of the element carbon. Nevertheless, the ignition of the gases having been effected in air, it was conceivable that hydrogen, nitrogen, or oxygen had influenced the phenomena. To eliminate this possible source of error, the experiments were repeated out of contact with air. A thin glass tube I inch in diameter and 3 inches long, with platinum wires fused into its sides, and its ends prolonged by glass quills having a capillary bore, was filled with pure dry cyanogen, and the greater portion of this gas then removed by a good air-pump. Another tube was similarly prepared with olefiant gas. The platinum wires in these tubes were then so connected with each other that the electric discharge from a powerful induction-coil could pass through both at the same time. On now observing the spectra of these two lights in the simultaneous manner previously described, the characteristic lines of the hydrocarbon spectrum were found to be rigidly continued in that of the nitrocarbon. Moreover, by the same method of simultaneous observation, the spectrum of each of these electric flames, as they may be termed, was compared with the corresponding chemical flames, that is, with the oxyhydrocarbon and oxynitrocarbon jets of gas burning in air. The characteristic lines were present in every case. Lastly, by similar inter-observation a few other lines in the electric spectrum of the hydrocarbon were proved to be due to the presence of hydrogen, and several others in the electric spectrum of the nitrocarbon to be caused by the presence of nitrogen. . . ."

"The spectrum under investigation having then been obtained in one case when only carbon and hydrogen were present, and in another when all elements but carbon and nitrogen were absent, furnishes, to my mind, sufficient evidence that the spectrum is that of carbon."

"But an interesting confirmation of the conclusion just stated is found in the fact that the same spectrum is obtained when no other elements but carbon and oxygen are present, and also when carbon and sulphur are the 
only elements under examination. And first with regard to carbon and oxygen. Carbonic oxide burned in air gives a flame possessing a continuous spectrum. A mixture of carbonic oxide and oxygen burned from a platinum-tipped safety-jet also gives a more or less continuous spectrum, but the light of the spectrum has a tendency to group itself in ill-defined ridges. Carbonic oxide, however, ignited by the electric discharge in a semi-vacuous tube, gives a bright sharp spectrum. This spectrum was proved, by the simultaneous method of observation, to be that of carbon plus the spectrum of oxygen. With regard to carbon and sulphur almost the same remarks may be made. IBisulphide of carbon vapour burns in air with a bluish flame. Its spectrum is continuous. Mixed with oxygen and burned at the safety-jet, its flame still gives a continuous spectrum, though more distinctly furrowed than in the case of carbonic oxide; but when ignited by the electric current its spectrum is well defined, and is that of carbon plus the sulphur. That is to say, it is the spectrum of carbon plus the spectrum that is obtained from vapour of sulphur when ignited by the electric discharge in an otherwise vacuous tube."

"Having thus demonstrated that dissimilar compounds containing carbon emit, when sufficiently ignited, similar rays of light, I come to the conclusion that those rays are characteristic of ignited carbon vapour, and that the phenomena they give rise to on being refracted by a prism is the spectrum of carbon."

This question was next taken up by Morren. He wrote ${ }^{1}$ (in 1865 ) fifteen years ago :-

"A la réception de cet intéressant et substanticl Mémoirc, j'avoue que je ne regardai pas d'abord comme fondée l'assertion de M. Attfield. . . .

"Je me suis donc mis au travail avec la pensée préconcue de combattre l'assertion émise par le savant anglais; mais pas du tout, il résulte au contraire des expériences auxquelles je me suis livré que $\mathrm{M}$. Attfield a raison, et que c'est bien la vapeur du carbone qui donne le spectre indiqué plus haut. . .

"Si on fait brûler le cyanogène au mojen du chalunieau à deux courants, en faisant arriver au centre de la flamme du cyanogène un courant d'oxygène très-pur (cette condition est indispensable), on voit se produire un des plus beaux effets de combustion possible, et cette cxpérience est certainement une des plus magnifiques qu on puisse réaliser sur la combustion des gaz. Il se produit, au milieu de la flamme rosé-violâtre du cyanogène, une boule d'un blanc vert éboulissant qui rappelle la lumière électrique produitc par le courant de la pile entre deux charbons de cornue. Si le spectroscope est dirigé sur cette brillante lumière, on aperçoit, avec une splendeur merveilleuse, le même spectre de la partie bleuc des flammes hydrocarburcées. Ainsi donc c'est du charbon seul, mais à l'état de vapeur, qui forme cette boule brillante qui plus loin, par son union avec l'oxygène, va passer à l'état d'acid carbonique. Du restc ce spectre n'est pas seul; avec lui on voit, mais très effacé, le spectre spécial du cyanogène, et celui-ci tend de plus en plus à disparaître à mesure que l'oxygène arrive avec plus d'abondance et brûle de mieux en mieux le cyanogìne. Quant au spectre de l'azote, on ne l'aperçoit pas dans cette vive lumière. Le magnifique éclat de ce beau spectre, le plus beau qu'il m'ait été donné de voir, permet de bien comprendre l'aspect creusé et ombré avec une teinte croissante qu'on remarque dans les parties qui n'ont pas de raies brillantes, et même entre ces raies."

Four years later Dr. Watts devoted himself to this subject, and in 1869 his work was thus summarised by himself : ${ }^{2}$ -

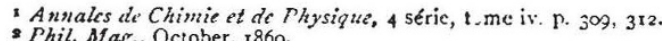
s Phil. Mfas., October, 1869 .
"This spectrum [that consisting of the flutings in question] may be obtained from the flame of any hydrocarbon, though in many cascs, owing to the faintness of the spectrum, only some of the groups can be recognised. In the flame of an ordinary I3unsen burner $\delta$ and $\epsilon$ are easily seen, $\gamma$ and $f$ are much fainter, and the red group cannot be detected.

" This spectrum is proved to be that of carbon, inasmuch as it can be obtained alike from compounds of carbon with hydrogen, with nitrogen, with oxygen, with sulphur, and with chlorine. I have obtained it, namely, from each of the following compounds:-olefiant gas, cyanogen, carbonic oxide, naphthalin, carbonic disulphide, carbonic tetrachloride, amylic alcohol, and marsh-gas."

That these conclusions, successively arrived at by Attfield, Morren, and Watts, are sound, I shall show in my next notice.

J. NORMAN LOCKYF.R

(To be continued.)

\section{SCIENCE IN PARLIAMENT}

THE House of Commons is now complete; all the boroughs and counties have made their choice, and the composition of the new Parliament has been and will be criticised from many points of view. So far as the interests of science and of what we conceive to be good education are concerne 1 , there is, we fear, little diference between the present House of Commons and its predecessor; just a thin ray of light athwart a cloud of darkness, a tiny morsel of knowledge in a mass of ignorance. This ignorance, however, we are bound to believe is not wilful ; we must admit that our new rulers are willing to be enlightened, unless in time they should show themselves otherwise disposed.

On this ground, as well as on others, it is to be lamented that one of the most eminent and useful scientific members of the House has lost his seat through some local caprice. The absence of Sir John Lubbock from the new Parliament is one we are sure every true lover of science will deplore. Where there is so much ignorance to be overcone, it seems to us we cannot have too many representatives of science in Parliament; and we are sure all who desire to sec science advanced in this country would welcome any chance of getting Sir John back to his old place. Such an opportunity has, some may think almost providentially, presented itself in the vacancy that has occurred in the representation of London University by the promotion of Mr. Lowe to "another place." Scveral candidates have been proposed for the vacant scat, but alongside of Sir John Lubbock all must strike an impartial onlooker as singularly unsuitable. The "doctors" have been attempting to put in a strong claim to have themsclves specially represented, supporting their cause, so far as London University is concerned, by somewhat shaky statistics. But medicine has no lack of friends in both Houses of Parliament; the claims which it has on the country are patent to all, and it is, moreover, included under the wider region of science. If the latter gets fair play from Government, medicine need have no fear that her claims will be ncglected. Already are two Scottish universities represented by Dr. Lyon Playfair, who is nothing if not medical. Not one of. our English universitics has a man of science as its representative, and it is surely important that an institution in which science holds so prominent 